Teaching
Methods

\section{Developing a Recruiting Video for Turfgrass Management}

\author{
David J. Wehner
}

Additional index words. students

Summary. A 14-min video highlighting careers in turfgrass management ("Turfgrass Management: Your Field of Dreams") was developed as a recruiting tool for colleges and universities. The intended audiences are high school students, parents, and members of the industry. The project was funded by commercial sponsors, and the video was produced at the Univ. of Illinois. The tape has received excellent reviews from instructors in turfgrass management and has been credited with increasing interest in their programs.

$\mathrm{T}$ he decline in enrollments in colleges of agriculture during the 1980s helped focus on the need to recruit students. Childers (1989) warned that a substantial effort was needed to recruit students successfully into horticulture or the deficiency in student numbers would have an adverse effect on leadership and advancement of the horticultural industry. In his analysis of enrollment trends and recruiting strategies in horticulture, Rhodus ( 1990) suggested strategies that a) develop materials that highlight departmental programs and career op- portunities; b) make these available to undecided majors, college and high school counselors, and alumni at career days; and c) provide travel funds for prospective students.

It is difficult for most faculty members to devote a large portion of their time to recruiting efforts. However, they can provide assistance by helping develop materials such as brochures and videotapes that are a component of a comprehensive recruiting strategy. The purpose of this report is to relate my experiences with developing a video to help recruit students in turfgrass management. These experiences may be useful to those interested in similar projects.

\section{Funding considerations}

Because of the high cost associated with producing a quality video, we decided to develop a video that promoted careers in turfgrass management rather than specific information about majoring in turf management at the Univ. of Illinois. We believed that a video applicable to a broad audience would be of more interest to potential commercial sponsors. It also was decided to try to secure several substantial sponsorships rather than many small contributions to the project. A preliminary letter was sent to $\approx 15$ potential sponsors, consisting of major companies involved in supplying equipment or materials to the turfgrass industry. After the initial inquiries, three companies indicated their willingness to evaluate a project proposal. These companies received a project proposal and sample video.

\section{Developing the project proposal}

The project proposal contained the following information: How the subject matter would be presented, who would produce the tape, how it would be distributed, and the budget. The purpose of the tape was to promote career opportunities in turfgrass management rather than serve as an educational video covering all of the duties of a turfgrass manager or providing in-depth information about turfgrass management curricula. As such, careers in the golf course, athletic field, and landscape maintenance industries, the lawn care industry, and sales of turfgrass products and services would be covered. The career opportunities would be presented by interviewing successful individuals in each of these areas.

There are multiple choices for a video production company. They consist ofexternal video production houses and university groups, either in the agricultural communications area or in the area of university public relations. External groups are usually more expensive because their operations are not partially subsidized by the state. It is important to request and review sample tapes from potential production units. It was thought that the video group in the Univ. of Illinois Office of Public Affairs had more experience in promotional videos, and they were chosen for the project rather than the agricultural communications group, which was very skilled in educational videos.

The cost of a video project can be estimated by using the rule of $\$ 1000$ per minute of finished video. Additional finding must be added to cover the cost for any special visual effects (usually these must be done in a commercial studio) and any traveling to secure the necessary footage. In our case, because of the diversity of turfgrass facilities in Illinois and because the university has a Chicago campus, we were able to combine travel for this project with other video projects or trips to Chicago to conduct other campus business. Promotional videos are typically in the 8 - to $12-\mathrm{min}$. range; thus, we believed it would be necessary to secure funding commitments of $\$ 15,000$ to cover the cost of production and distribution of the tape. Included with the proposal was a short segment of video to demonstrate the quality of production afforded by the Office of Public Affairs. In order to make the project appeal to sponsors, it was decided that their logo and a state- 
ment about their business would be included at the end of the tape, as is done on public television. No editorial control was given to the sponsors other than a courtesy review of the tape prior to the final distribution. Sponsor commitments were secured from three corporations (CIBA-GEIGY, Deere \& Co., and Spraying Systems Co.) and the Illinois Turfgrass Foundation. Note that the advertising and marketing groups in the corporations have control over funds used for promotional purposes; thus, it saves time if these groups are approached directly.

\section{Developing an outline for the video and a narrator's script}

An outline for the video and a narrator's script were needed before shooting started in order to minimize unnecessary filming. The outline contained the order in which the careers would be presented, and the narrator's script provided transitions between the careers as well as introductory information about turfgrass management.

\section{Taping episodes}

Industry representatives were asked questions about what they liked about their positions, what type of experience and education they had, and what the future outlook was for their profession. By obtaining their natural reaction to each question, we avoided the appearance of the individuals having memorized a script (remember that these individuals were not trained actors). Because turfgrass management programs are offered as 2- and 4-year programs, certificate and degree programs, and are offered within horticulture, agronomy, and plant science departments, care was taken to ensure that the discussion of educational background was not biased towards any particular type of program. Each individual was interviewed in an appropriate setting, such as Comiskey Park (athletic field), Butler National Golf Club, and McDonald's corporate headquarters (landscape maintenance). A truck was borrowed from a local lawn care firm to use as a prop for the lawn care interview.

We taped the individuals interacting with people or performing other supervisory functions because the video was intended to stress the management rather than the labor aspects (mowing, fertilizing, etc.) of each career. In addition to the industry representatives, several students were interviewed to determine what they liked about their chosen field of study and their experiences at finding a position.

\section{Compiling the tape, final review, and distribution}

The tape was compiled to feature the most-articulate spokesperson for each career opportunity and the best portions of his/her interview. Stack and Perry (1992) cited the top three interests of high school students as sports, earning money, and recreation. Because two of the career opportunities-golfcourse and athletic field man agement-are frequently associated with high-profile professional sporting events, scenes from a golf tournament and a baseball game were used to introduce the subject matter and as transitions between some of the career information. The event footage was obtained from local television stations.

Final review consisted of each sponsor's viewing the tape and providing suggestions for changes. One change was incorporated; a scene of an individual applying pesticide without rubber gloves was replaced with one in which the applicatorwas wearing gloves. A copy of the master tape was sent to an outside video company for duplication; a complimentary copy of the finished VHS-format tape was sent to each college and university in the United States, Canada, and England with a turfgrass management program in Spring 1991. The cost of producing the tape is presented in Table 1. The cost of duplication and distribution was about $\$ 800$.

Table 1. Production costs for the video "Turfgrass Management: Your Field of Dreams.”

\begin{tabular}{llr}
\hline Item & Hours/quantity & Cost $(\$)$ \\
\hline Video shooting & $50 \mathrm{~h}$ & 5750.00 \\
Video recording & $2 \mathrm{~h}$ & 99.00 \\
Audio music & & \\
production & $1 \mathrm{~h}$ & 56.00 \\
Video editing & $55 \mathrm{~h}$ & 5500.00 \\
Scripting/ & & \\
$\quad$ development & $30 \mathrm{~h}$ & 660.00 \\
Music royalties & $4 \mathrm{cuts}$ & 528.00 \\
Duplication costs & $3 \mathrm{~h}$ & 155.00 \\
Materials & - & 654.00 \\
Travel time & $25 \mathrm{~h}$ & 412.50 \\
Total & & $13,814.50$ \\
\hline
\end{tabular}

\section{Using the video in a recruiting program}

The video has received excellent reviews from turfgrass management instructors across the United States. Most of the responses indicated that the video was being shown to students in introductory turfgrass management courses and to appropriate groups of potential students. The most successful use of the video that I am aware of has occurred at Iowa State Univ., in the Dept. of Horticulture. Nick Christians (personal communication) has used the video as part of a recruiting program for turfgrass management students. He sends a copy of the video with a postage-paid return envelope to high school guidance counselors in Iowa. The counselors have shown the tape to groups ofstudents, and this has generated interest in turfgrass management. His program is credited with a $30 \%$ increase in the number of turfgrass management students enrolled over a 2-year period.

\section{Suggestions for those considering a video project}

Anyone considering a video project should keep several thoughts in mind. First, a comprehensive marketing plan should be developed to determine how the video can be used, who the intended audience is, and who the potential sponsors are. If commercial sponsors are sought, approach the marketing and advertising groups for each potential sponsor. Second, consider using a video producer who has expertise in promotional videos. An educational video may be a worthy goal, but this type of video can be boring to young people. Third, do not write a script for individuals you are interviewing. Finally, consider how much time you can invest in this type of project.

\section{Literature Cited}

Childers, N.F. 1989. Accumulated philosophy on student recruiting, teaching, research, and funding in horticulture. HortScience 24(6):895-896.

Rhodus, W.T. 1990. Analysis of recent enrollment trends and recruiting strategies in horticulture. HortScience 25(11):14431446 .

Stack, L.B. and L.P. Perry. 1992. Careers in horticulture: The video. HortScience $27(5): 386,486-487$. 